\title{
LECTOTYPIFICATION AND A NEW SYNONYM OF BONAMIA SERICEA (CONVOLVULACEAE): ENDEMIC SPECIES FROM Argentina
}

\author{
LECTOTIPIFICACIÓN Y UN NUEVO SINÓNIMO DE BONAMIA SERICEA \\ (Convolvulaceae): Especie endémica de Argentina
}

\section{André Luiz Da Costa Moreira ${ }^{*}(\mathbb{D})$, Rosângela Simão-Bianchini² ${ }^{2}$ and Taciana Barbosa Cavalcanti ${ }^{3}$ (D)}

1. Universidade de Brasília Programa de Pós-Graduação em Botânica, Campus Darcy Ribeiro, Departamento de Botânica, 7091900, Brasília, DF Brasil.

2. Núcleo de Pesquisa Curadoria do Herbário SP, Instituto de Botânica, Caixa Postal 68041, São Paulo, SP, Brasil.

3. Embrapa Recursos Genéticos e Biotecnologia, Parque Estação Biológica, Final W5 Norte, C. Postal 02372, 70770-900 Brasília, DF, Brasil.

*biologobotanico@gmail.com

Citar este artículo MOREIRA, A. L. C., R. SIMÃOBIANCHINI \& T. BARBOSA CAVALCANTI. 2020. Lectotypification and a new synonym of Bonamia sericea (Convolvulaceae): Endemic species from Argentina. Bol. Soc. Argent. Bot. 55: 45-51.

DOI: https://doi. org/10.31055/1851.2372.v55. n1.24823

Recibido: 27 Junio 2019 Aceptado: 17 Diciembre 2019 Publicado: 25 Marzo 2020 Editor: Franco E. Chiarini (DD

\section{Summary}

Background and aims: Bonamia Thoaurs (Convolvulaceae) comprises about 70 species with a tropical and subtropical distribution. Morphological and molecular studies in Bonamia were carried out to clarify relationships in and out of the genus and throughout this work it was detected the need for re-limit the circumscription of some taxa. This paper contributes to the circumscription and lectotypification of Bonamia sericea (Griseb.) Hallier f., an endemic species from northern Argentina.

M\&M: Morphological analysis of Bonamia sericea, were made based on a study of specimens of herbaria, including the type-material, digital type images and other herbaria website.

Results: A new synonym for $B$. sericea is proposed. The lectotype of $B$. sericea is here designated and a complete description and illustrations are presented.

\section{KeY Words}

Endemic species, lectotypification, synonym, taxonomy.

\section{RESUMEN}

Introducción y objetivos: El género Bonamia Thoaurs (Convolvulaceae) comprende alrededor de 70 especies con distribución tropical y subtropical. Durante análisis morfológicos y moleculares de Bonamia se detectó la necesidad de delimitar algunos taxones. Este artículo contribuye a la circunscripción y la lectotipificación de Bonamia sericea (Griseb.) Hallier f., una especie endémica del norte de Argentina. M\&M: Análisis morfológico de Bonamia sericea fue realizada mediante préstamo de especimes, incluidos los tipos, y imágenes digitales disponibles en línea, y se compararon con las descripciones originales del taxón.

Resultados: Se propone un nuevo sinónimo para $B$. sericea y se designa su lectotipo. Se realiza una descripción completa de su distribución geográfica.

\section{Palabras Clave}

Especies endémicas, lectotipificación, sinónimos, taxonomía.

\section{INTRODUCTION}

Bonamia Thouars (Convolvulaceae) comprises 69 species (WCSP, 2017; Moreira et al., 2019), with a wide distribution over tropics and subtropics, including representatives in the Americas, Africa, Madagascar, South and Southeast Asia and Australia (Staples, 2012; Wood, 2013).

The taxonomy of the genus Bonamia went through extensive modifications in its delimitation: Choisy (1845) treated Bonamia, Breweria R.Br., Stylisma Raf., Seddera Hochst., and Prevostea Choisy as distinct genera. Hallier (1893) highlight the weakness of the differences and combined Breweria in Bonamia. In the most extensive review of the genus, Myint \& Ward (1968) established the sections Breweria (R.Br.) Myint, and Trichantha Myint, encompassing the 45 species previously recognized and distributed through the old and the new world. 
Traditionally the pollen morphology data, details of gynoecium and the fruits are used by taxonomists to delimit genera in Convolvulaceae, in this way Bonamia can be distinguished from the other genera for presenting generally pollen 3-colpate, with ornamentation reticulated or microreticulated, the styles divided into two filiform branches with globose to reniform stigmas, and the fruits are capsules (2-) 4-8 valvate, chartaceous to woody.

The present study analyzes the infraspecific delimitation and the lectotypification of Bonamia sericea (Griseb.) Hallier f. providing a description, data about geographic distribution and photos of the lectotype proposed.

\section{Material ANd Methods}

The results were obtained from the morphological analysis using herbarium specimens, including type materials, on loan from the herbaria $\mathrm{GH}$, L, MO, NY, SP, UB, UEC (acronyms follow Index Herbariorum: http://sweetgum.nybg.org/ih/). Digital images available in JSTOR - Global Plants (https://plants.jstor.org/). The original descriptions of both varities were compared with the examined material.

\section{Results}

Bonamia sericea (Griseb.) Hallier f., Bull. Herb. Boissier 5: 808. 1897.

$\equiv$ Breweria sericea Griseb., Plantae Lorentzianae 19: 229 (reprinted 181). 1874. Convolvulus breweraceus O.Kuntze, Rev. Gen. 3: 212. 1898. A new name for Breweria sericea Griseb., non Convolvulus sericeus Burmann f. (1768). - Type: Argentina. Cordoba: in den Barrancas bei Cordoba, haufig 1870, Lorentz 82. (Lectotype here designated GOET, image!; isolectotypes: $\mathrm{B} \dagger$; CORD image!, SI). (Fig. 1-2)

= Bonamia sericea var. latifolia O'Donell, Lilloa 29: 314. 1959. Type. Argentina. Santiago del Estero: El Palomar a Pampa Poza, 15 Nov. 1931, Schreiter 6706 (holotype LIL!; isotypes: GH image!, NY!). Syn. nov. (Fig. 3)

Caespitose shrubs; stems erect or procumbent, woody basally, herbaceous toward the tips, arising from a woody root, $15-40 \mathrm{~cm}$ tall, densely to sparsely sericeous with appressed trichomes. Leaves petiolate, petioles 1-7 mm long, blades elliptic, ellipticlanceolate to elliptic-ovate, $8-35 \mathrm{~mm}$ long, 3-20 mm wide, base obtuse, acute or attenuate, apex obtuse to acute, mucronate, coriaceous to subcoriaceous sericeous in both surfaces. Inflorescences axillary, sometimes terminal, solitary or in cimes, peduncles 3-10 $\mathrm{mm}$ long, sericeous, pedicels $2-5 \mathrm{~mm}$ long, sericeous, bracts linear to narrow-lanceolate, 2-3 $\mathrm{mm}$ long. Flowers white, sepals subequal, $7-10 \mathrm{~mm}$ long, 3-5 mm wide, ovate, acute, often acuminate, concave; corolla funnelform, $15-30 \mathrm{~mm}$ long, white, ferrugineous on the interplicae; stamens included, filaments glandular villous at base, glabrous distally, subequal, anthers 3-5 mm long, oblong, basally sagittate; pollen 3-colpate, smooth; ovary conical, densely hirsute in the apex, glabrous at the base, styles unequal, 12-14 mm long, bifid above middle, stigmas globose. Capsules, subglobose to conic, 5-6 mm wide, apex hirsute, mostly 4-valved, brown; seeds 1-4, black, 3-5 mm long, glabrous.

Geographic distribution. Endemic to Argentina, with records for Córdoba, La Rioja, San Luis, Santiago del Estero, and Tucumán.

Additional comments. The individuals of Bonamia sericea are shrubs that grow in dry areas in northern Argentina, in elevations of $400-500 \mathrm{~m}$. It was collected in flower in April, and October to December, and fruits in December.

Morphological analysis of several specimens provided the observation that the variety $B$. sericea var. latifolia (O'Donell 1959: 314, fig. 50) based on the variations found in the indumentum density and leaf width (3-20 mm), is not supported.

Myint \& Ward (1968) in the revision of the genus, recognized the varieties and used the following characteristics in the key to separate the varieties: Bonamia sericea var. sericea has densely sericeous small leaves, with 3-10 mm long. while Bonamia sericea var. latifolia has sparsely sericeous or puberulent indument and larger leaves, with 4-20 mm long.

The characteristics used by the authors, O'Donell (1950) and Myint \& Ward (1968), as leaf size and vestiture are broadly variable and overlap in the specimens analyzed. It is well known that the species in the family have very plastic morphological 


\section{A. L. C. Moreira et al. - Bonamia sericea (Convolvulaceae)}

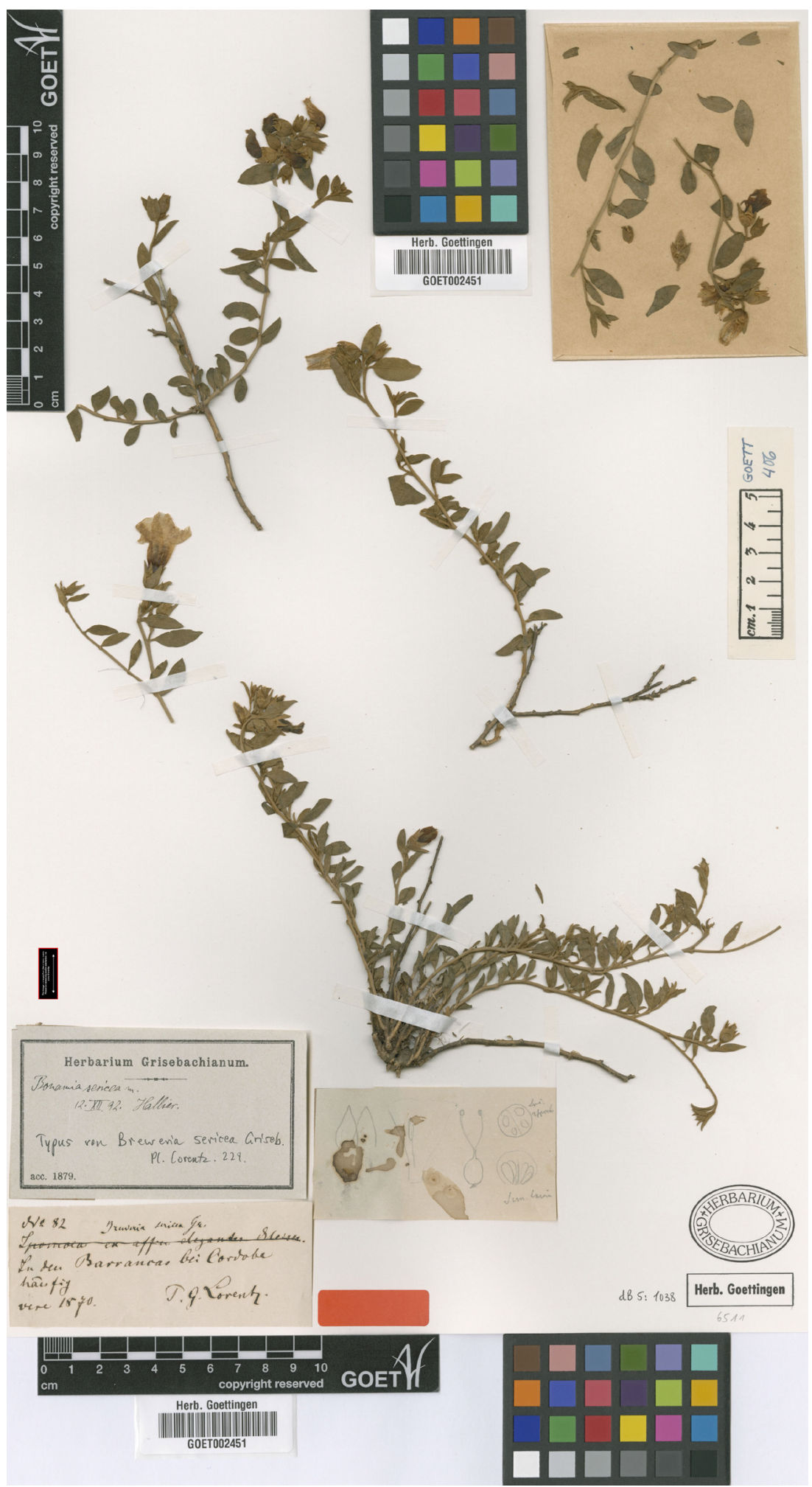

Fig. 1. Lectotype of the specimen of Breweria sericea Griseb. [Lorentz 82] deposited in the herbarium GOET. 
Bol. Soc. Argent. Bot. 55 (1) 2020

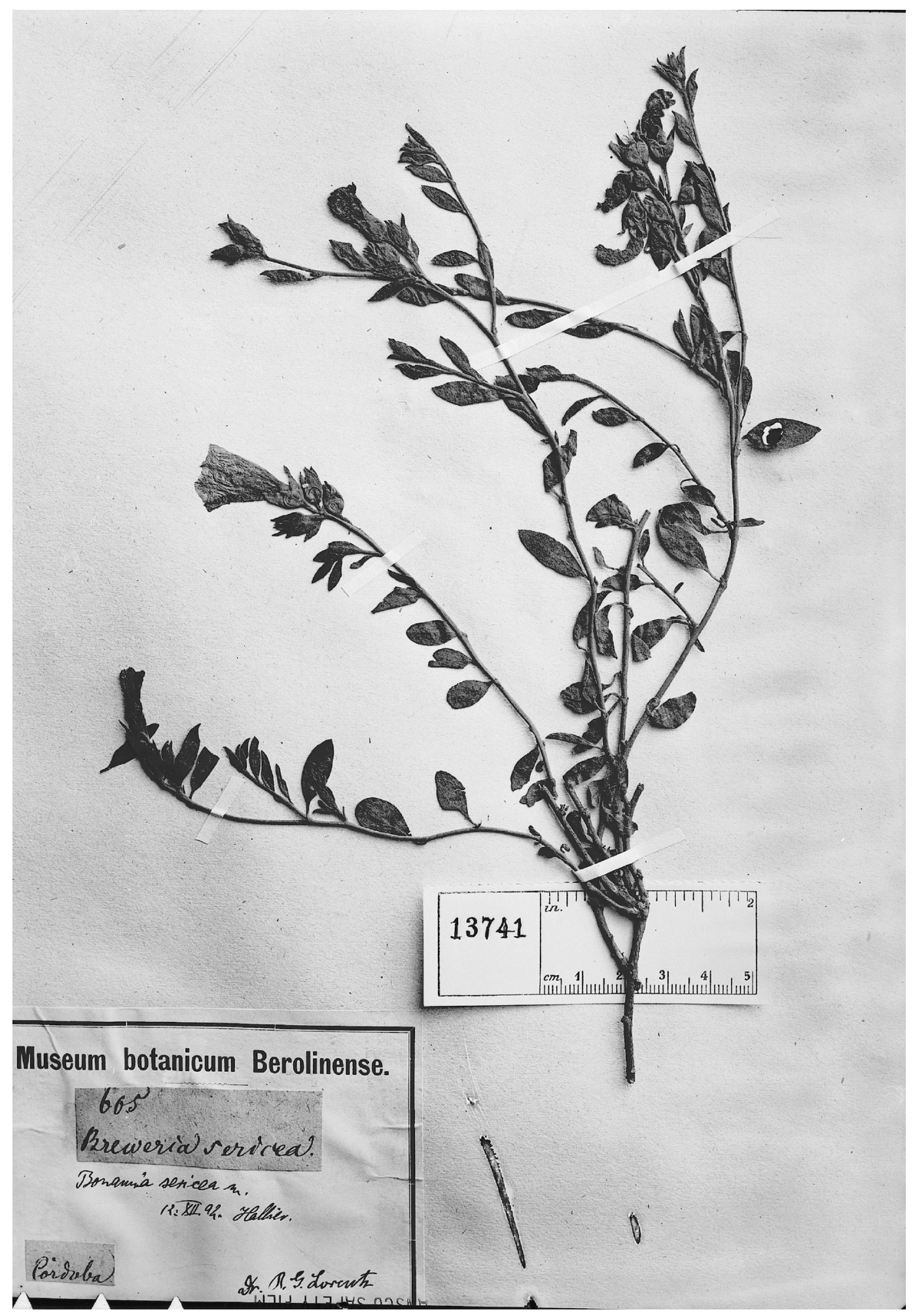

Fig. 2. Syntype of the specimen Breweria sericea [Lorentz 605] deposited in the herbarium $B(\dagger)$. 


\section{A. L. C. Moreira et al. - Bonamia sericea (Convolvulaceae)}

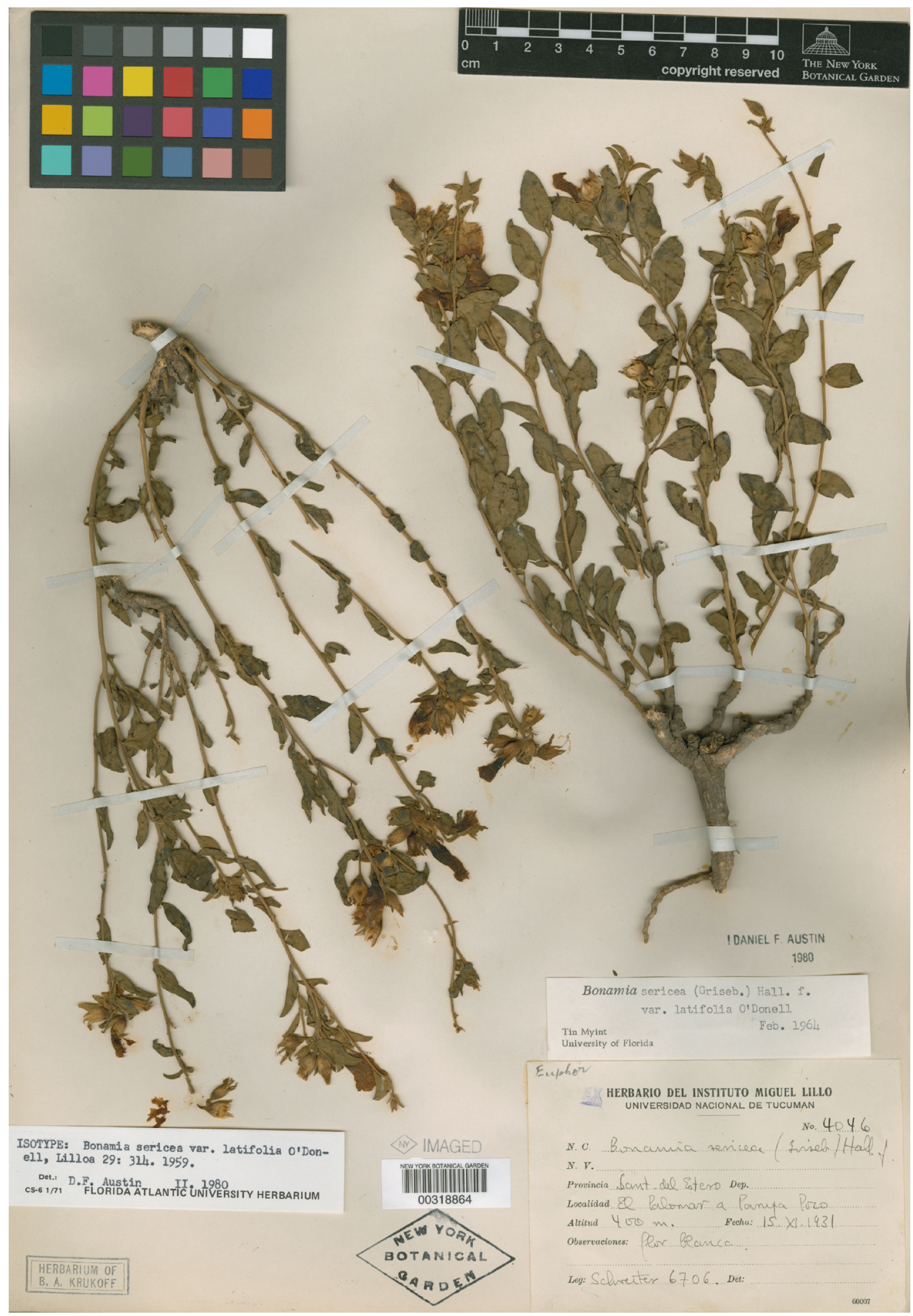

Fig. 3. Holotype of the specimen Bonamia sericea var. latifolia O'Donell [Schreiter 6706] deposited in the herbarium LIL. 
characteristics (Buril, 2013), and so it may be related to environment influence.

When Grisebach (1874) published Breweria sericea, he did not refered material, but he was naming the material collected by P.G. Lorentz. The exsiccate of Bonamia sericea "Lorentz 82" in GOET herbarium is here considered as the lectotype, because there is a hand drawing of opened flower, showing the gynoecium, and this is the institution where Grisebach worked. Hunziker (1960: 364) indicated the gathering Lorentz 82 as isotype in a list of the material from Herbarium CORD described by Grisebach, so he believed that this collection indeed was used to the description.

Material Examined. ARGENTINA. Córdoba: 18. V.1945, P. Garcia 941 (GH); 18.VI.1923, R. Schreiter 3956 (GH); 21. X.1923 S. Venturi 2074 (GH); 7.VI.1944, R. Diaz 110272 (GH); 17.III.1944, C.A. O Donell 329 (GH, USA); 20.I.1940, De La Veja 90 (MO); 8.XII. 1946, A.T. Hunziker 7070 (MO); 22.XII.2009 J.J. Cantero \& C.O. Nuñez 6134 (UEC); 20.I.1947, C.A. O'Donell 4453 (RB); 14.XI.1947 C.A. O'Donell 5413 (RB), 8.XII.1946 A.T. Hunziker 7070 (CORD, MO); 20.I.1947 O'Donell, C.A. 4545 (RB); 14.XI.1947, C.A. O'Donell 5413 (RB); XI.1895 B.W. Rodenbender 8823 (R). Santiago del Estero: 15.XI.1931 R. Schreiter 4046 (NY). Cruz Alta, 21.X.1923, S. Venturi s.n. (SI SI069079). Tucumán: 14.XI.1947 C.A. O'Donell 5413 (RB, UB).

\section{Contribution of Authors}

ALCM and RSB were responsible for the organization of the manuscript and for the morphological analysis and TBC collaborated in writing the manuscript.

\section{ACKNOWLEDGEMENTS}

We are grateful to the herbaria curators for making the type collections images available online. The authors thank the support of Coordenação de Aperfeiçoamento de Pessoal de Nível Superior (CAPES-finance code 001), for the doctoral fellowship of the first author and to the Conselho Nacional de Desenvolvimento Científico e Tecnológico (CNPq) process $311738 / 2016-8$, for the research grant of the second author.

\section{Biblography}

BROWN, N.E. 1914. Diagnoses africanae LIX. Bull. Misc. Inform. 1914: 167-171. https://www.jstor.org/ stable/4115402

BROWN, R. 1810. Prodr. Florae Novae Hollandiae. Typis Richardi Taylor et Socii, Edimburg. http://dx.doi.org/10.5962/bhl.title.397

BURIL, M.T. 2013. Sistemática e Filogenia de Jacquemontia (Choisy), Convolvulaceae. Tese de Doutorado, Universidade Federal de Pernambuco, Recife. Brasil.

DEGENER, O. 1932. Perispermum, Fam. 307. In: O. DEGENER, Fl. Hawaiiensis, Honolulu.

GRISEBACH, A. 1874. Plantae Lorentzianae. Abhandlungen der Konigliche Gesellschaft der Wissenschaften, Gottingen 19: 164166.

HUNZIKER, A.T. 1960. Catalogo de los tipos "Gresebachianos" conservados em Cordoba. Bol. Acad. Nac. Ci. 2: 283-405.

KARSTEN, H. \& J. J. TRIANA. 1856. Plantae Columbianae. Burmeistera Karst. et Triana. Lobeliacearum gen. nov. Linnaea 28: 444-446.

MOREIRA A. L. C., G. M. ANTAR, R. SIMÃOBIANCHINI \& T. B. CAVALCANTI. 2017. Contribution to the knowledge of Bonamia (Convolvulaceae) in Brazil: A new species and a new occurrence. Phytotaxa 306: 146-152. http://dx.doi. org/10.11646/phytotaxa.306.2.4

MOREIRA A. L. C., R. SIMÃO-BIANCHINI \& T. B. CAVALCANTI 2018. Two new species of Bonamia (Convolvulaceae) endemic to the Brazilian Cerrado. Phytotaxa 361:106-114.

http://dx.doi.org/10.11646/phytotaxa.361.1.9

MOREIRA A. L. C., R. SIMÃO-BIANCHINI \& T. B. CAVALCANTI. 2019. Bonamia linearifolia (Convolvulaceae), a new species from the Brazilian Cerrado. Kew Bull. 74: 10. http://dx.doi.org/10.1007/S12225-019-9798-1

MYINT, T. \& D. B. WARD 1968. A Taxonomic revision of the genus Bonamia (Convolvulaceae). Phytologia 17: 121-237. https://www.biodiversitylibrary.org/ part/30181\#/summary

ROBERTY, G. 1952. Genera Convolvulacearum. Candollea 14: 11-60.

STAPLES, G. 2012. Convolvulaceae Unlimited - The Morning glories and bindweeds. [online]. Available en: http:/convolvulaceae.myspecies.info. [Acceso: 25.01.2019].

WCSP, 2018.'World Checklist of Selected Plant Families. 


\section{A. L. C. Moreira et al. - Bonamia sericea (Convolvulaceae)}

Facilitated by the Royal Botanic Gardens, Kew [online]. Disponible en: http://apps.kew.org/wcsp. [Acceso: 25.01.2019].
WOOD, J. R. I. 2013. Bonamia (Convolvulaceae) in Bolivia. Kew Bull. 68: 1-12.

http://dx.doi.org/10.1007/s12225-013-9452-2 
